and sera laboratories, less than ten are engaged in research work.

The DHSS is confident that any gap in the UK and export demand for vaccines can be supplied by the other two UK manufacturers, Wellcome and a subsidiary of Glaxo. It was decided not to grant $£ \frac{1}{2}$ million to the Lister Institute because it was reluctant to finance a commercial undertaking, especially when there were other competitive manufacturers, and because it felt that more than $£ \frac{1}{2}$ million would be needed to fund the Institute's plans.

When the Chelsea property and the vaccine and sera laboratories are finally sold the Institute plans on using the proceeds to further research into immunology. Just how it will do that will not be known until it knows how much money will be available.

Judy Redfearn

\section{Scientists prepare for UNCSTD}

Ат a meeting called by the International Council of Scientific Unions (ICSU) in Paris last January, a steering committee was set up to consider what the non-governmental organisations (NGOs) in science and technology can contribute to the United Nations Conference on Science and Technology for Development (UNCSTD) which is to be held in Vienna next August. The committee has already started organising a symposium which will probably be the most important preliminary to UNCSTD so far as the world scientific community is concerned. It is scheduled for January 1979 and will be held in a developing country-possibly Singapore-where the 70 or so scientists and others being invited will meet for six working days.

The steering committee is chaired by Dr T. F. Malone, director of the Holcomb Institute, Butler University, and convened by Maurice Goldsmith, director of the Science Policy Foundation, London. Little difficulty is anticipated in financing the symposium.

ICSU emphasises that the objective of the steering committee is not to involve scientists directly in the proceeding of UNCSTD, which is now accepted as essentially a political conference, although it is hoped that wherever possible, scientists will be included in national delegations. The aim is also to see what can be done to continue whatever comes out of the conference that is of concern to the scientific community. Put in somewhat pompous officialese, it is "to explore institutional and other innovations which would enlarge and enhance opportunities for scientists and engineers to participate in future years in the contributions of science and tech- nology to the improvement of the human condition". The stress is on continuing activity, and this is in line with the ideas of such other nongovernmental organisations as the Pugwash Conference, the World Federation of Engineering Organisations (WFEO), and the International Social Science Council (ISSC) involved on the outer perimeter of the conference preparations.

Pugwash has already had several meetings in developing countries to examine, amongst other things, the political, economic and even (where the multinational corporations are concerned) psychological problems that may arise for scientists when the conclusions of UNCSTD come to be applied in developing countries. The evolution of guidelines for study at the frontiers of science-especially in agriculture and energy - and the relationship between disarmament and development are other fields being examined by this group in the UNCSTD context.

For ISSC, things are somewhat different. It is felt that the social sciences should have been involved from the first, but in fact it was only at the recent Geneva meeting of the UNCSTD preparatory committee that ISSC appeared as an observer. ISSC feels that its members are only asked to help when the economists and technologists find that their theories are not being accepted or put into practice in the developing countries. Even the UN Development Programme excluded anything like sociology from its projects until recently: now that the fact is being appreciated that development deals with people, as well as economics and industry, the situation is changing. Certainly the experience of the social scientists will be needed if science and technology are to be usefully applied in the developing world.

Peter Collins

\section{Hungary happy with its science}

Hungarian science, like that of all Comecon countries, is channelled towards the needs of production. The expansion of $R$ \& $D$ needed for the "scientific-technological revolution" in the Hungarian economy made a somewhat slow start, so that in 1964-1969 only $78-82 \%$ of the direct nonrepayable government grants for $R$ \& $D$ were being taken up by the bodies concerned.

A recent report from the Central Committee of the Hungarian Socialist Workers' Party and the Academy of Sciences gives a more promising picture, however. This notes, approvingly, that the "over-all science policy has met the test in practice"

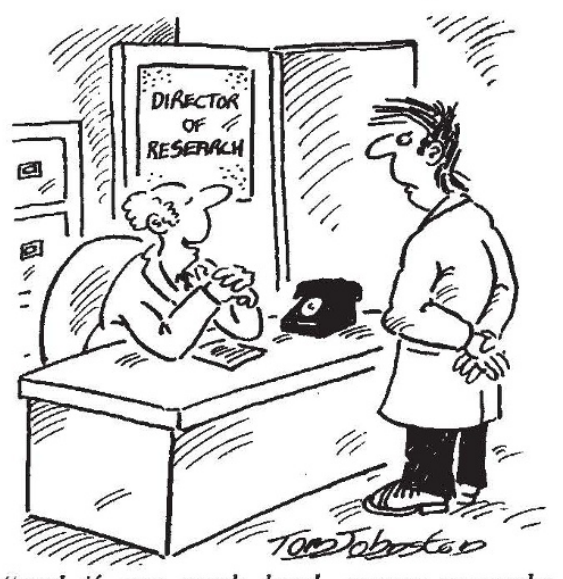

"and if you work hard, young comrade, you may one day get a key to the creators' washroom!"

(which, in Socialist terminology, refers first and foremost to the practice of the factory floor). Some $3.5 \%$ of the national income is now being spent on scientific research, while more than 80,000 persons are employed at the various research bases throughout the country.

This expansion, although gratifying to those who compile statistics of national achievements, is apparently causing some problems in practice. A recent broadcast on Budapest radio noted that as Hungarian science is now in a state of transition from "individual sovereignty" to "the necessity of project guidance", the number of scientific personnel is "statistically upsetting".

If the era of classical scientists has now gone by, it asked, is there any justification for the old concessions of flexible working hours, free days and sabbaticals to be granted in the name of "creative freedom"? At present, anyone with a diploma, who works in a research institute, is granted the "status of a scientist"- - even if he is only doing routine work, and is "someone who over several years has not produced any evidence; someone who has been searching, but discovered nothing". Why, it is asked, should the "privileges granted to creators" be extended to the "noncreative masses of specialists"?

The basic problem, said the speaker, is organisation. The ideal organiser should not be a stickler for "dictatorial project leadership" but should be someone able to "harmonise scientific objectives with the aspirations of researchers; a person who demands qualitative results, who is not merely of the managerial class, but a scientist who can win the respect of individualistic researchers". Preliminary research has shown that some scientists were disturbed and others stimulated by time-limits imposed on their creative thinking-a "diversity of individuality" which the wise project director would do well to respect.

Vera Rich 